\title{
Correlation Studies in Tomato (Lycopersicon lycopersicum L. Karst) as Affected by Mulching and Cultivar During the Heat Period in the Semi-Arid Region of Nigeria
}

\author{
A. S. Wali ${ }^{1, *}$, B. H. Kabura ${ }^{2}$ \\ ${ }^{1}$ Department of Farming System Research, Lake Chad Research Institute, Maiduguri, Nigeria \\ ${ }^{2}$ Department of Crop Production, University of Maiduguri, Borno State, Nigeria \\ *E-mail address: sherifwali@yahoo.co.uk
}

\begin{abstract}
Tomato though a day neutral crop, is predominantly cultivated during the cool dry harmattan partly due to low incidence of diseases and favourable low temperature. The scarcity of fresh tomato outside this season needs to be considered to meet the teeming demand of the populace. Knowledge of the nature of association between yield and its components is of great necessary in any breeding programme. It was against this background that a field experiment was conducted in 2008 and 2009 at Salam Farm of Ngaburari village of Konduga Local Government Area of Borno State (Lat. $12^{\circ} \mathrm{N}$ and Long. $13^{\circ} 13^{\prime} \mathrm{E}$ ) in the Semi-Arid Region of Nigeria to determine the relationship between yield and other agronomic parameters as affected by mulching and cultivars of tomato (Lycopersicon lycopersicum L. Karst) during the heat period to provide effective tool for breeders. The treatments consisted of five cultivars of tomato (Tandino, Danbaga, Roma VF, UC82B and Dansyria) and six grass mulch (Pennisetum pedicelatum Trin) levels ( $0 \mathrm{t} / \mathrm{ha}, 2.5 \mathrm{t} / \mathrm{ha}, 5 \mathrm{t} / \mathrm{ha}, 7.5 \mathrm{t} / \mathrm{ha}, 10 \mathrm{t} / \mathrm{ha}$ and 12.5 $\mathrm{t} / \mathrm{ha}$ ) which were laid out in a strip-plot design and replicated three times. The parameters studied include plant height, number of leaves, leaf area, leaf area index, number of branches per plant, days to first and $50 \%$ flowering, number of fruits, weight of fruits per plant and yield in $\mathrm{t} / \mathrm{ha}$. Data collected were subjected to Correlation Analysis using Statistic 8.0 and the results of the combined years for cultivars indicated that total fruits yield was significantly and positively correlated with plant height, number of leaves, leaf area, leaf area index, days to first flowering and weight of fruits but significantly negatively correlated with days to $50 \%$ flowering. Similarly, correlation of parameters as affected by mulch indicated significant and positive correlation of fruit yield with plant height, number of leaves, leaf area, leaf area index days to first flowering, number of fruits and weight of fruits but significantly negatively correlated with number of branches and days to $50 \%$ flowering. Days to first flowering had significant positive correlation with days to $50 \%$ flowering, number of fruits and weight of fruits both as affected by cultivar and mulch. Hence selection for high yield during heat period in the semi arid region of Nigeria should be based on earliness to flowering.
\end{abstract}

Keywords: tomato cultivars; grass mulching; Lycopersicon lycopersicum L. Karst; heat period; correlation; yield 


\section{INTRODUCTION}

Tomato is one of the most nutritive vegetables which are very rich in Vitamin A and Vitamin C, proteins, fats and carbohydrates, food energy calories as well as other essential minerals and food elements (Mahapatra et al., 2013). In Nigeria, tomato is mostly cultivated in the semi arid region during the cool dry season (harmattan period) using irrigation. High temperatures have been proved to have a detrimental effect on the delicate tomato fruitset process (Harel et al., 2014) hence the production of tomato is limited to the cooler period of the year (Rodriguez, 2007). As such, the availability of fresh tomato is always limited during the hot period (Wali and Kabura 2013; Kabura et al., 2009). During the hot period, temperature rises up to $40{ }^{\circ} \mathrm{C}$ in this region. Optimum day, night and soil temperatures for tomato production are $32{ }^{\circ} \mathrm{C}, 22{ }^{\circ} \mathrm{C}$ and $25^{\circ} \mathrm{C}$ respectively (Orzolek, 2000). One way to achieve improved production condition is the use of mulch. Mulching have been used to enhance productivity in tomato (Quinn, 1975; Ashrafuzaman et al., 2010) and other crops (Mata et al., 2002; Maged, 2006) through its effect particularly on soil environment in terms of soil temperature and moisture regulation, texture and fertility improvement (Lal et al., 1980; Sakar et al., 2007) and weed (Hudu et al., 2002) and pest control (Lawan, 2006). However, the degree of response to temperature stress differs with crop variety (Adil et al., 2003; Mitterbauer and Esch, 2007).

The knowledge of the relationship among plant characters and yield is useful while formulating selection scheme with target to improve yield. Correlation coefficient helps the breeder to select an efficient trait in a breeding programme and allocate appropriate weightage for optimal results (Maga et al., 2012). Correlation studies provide information that selecting one character will result in progress for all positively correlated characters (Marie and Mohammed, 2010). Many of the characters are correlated because of mutual association, positive or negative, with other characters. Information on the correlation studies of tomato under mulch during the heat period will be useful for breeders as such studies have so far received scanty attention. With the global warming phenomenon of increasing temperature, the challenges become more serious on how tomato will grow and develop under such condition. The pertinent questions are: can mulching enhance their performance? How significant will be the response of cultivars under such condition? These considerations prompted the need to carry out this study with the objectives to identifying the relationships between yield and other agronomic parameters with a view to improving them for higher tomato yield during the heat period in the semi-arid region.

\section{MATERIALS AND METHODS}

The experiment was conducted at Salam Farm in Ngaburari village of Konduga Local Government Area Borno State (Lat. $12^{\circ} \mathrm{N}$ and Long. 13 ${ }^{\circ} 13^{\prime}$ ) during the hot seasons (March to June) of 2008 and 2009. The field trial was a two factor experiment: five cultivars of tomato (Tandino, Danbaga, Roma VF, UC-82B and Dansyria) and six grass (Pennisetum pedicellatum Trin.) mulch levels $0 \mathrm{t} / \mathrm{ha}, 2.5 \mathrm{t} / \mathrm{ha}, 5 \mathrm{t} / \mathrm{ha}, 7.5 \mathrm{t} / \mathrm{ha}, 10 \mathrm{t} / \mathrm{ha}$ and $12.5 \mathrm{t} / \mathrm{ha}$ were laid out in a strip-plot design. The treatments were replicated three times in three blocks of $174 \mathrm{~m}^{2}$ and alleys between the blocks of $0.5 \mathrm{~m}$ width. Each of the blocks having thirty treatments plots each of $4 \mathrm{~m}^{2}$. The five cultivars of tomato were obtained from the Horticultural Unit of the Borno State Agricultural Development Programme (BOSADP) Maiduguri. These cultivars were chosen because they are among the most commonly grown 
tomato cultivars in this region. The grass mulch (Pennisetum pedicellatum Trin) used for the study was chosen because it is one of the common grasses in this region.

The experimental area was cleared manually and harrowed with a tractor. The land was properly leveled and the beds marked out. The edges of each bed were raised to prevent run-off during irrigation. The beds were then thoroughly watered for three days before transplanting. Fertilization was done based on Borno State Agriculture Development Programme, BOSADP (1993) recommendation. Basal application of $330 \mathrm{~kg} / \mathrm{ha}$ NPK $(15: 15: 15)$ at transplanting and top dressing with $100 \mathrm{~kg} / \mathrm{ha}$ urea in two split doses of 50 $\mathrm{kg} / \mathrm{ha}$ each at 3 weeks after transplanting (WAT) and 6 WAT.

The seedlings for each of the five (5) cultivars of tomato were raised in a $0.5 \times 1 \mathrm{~m}$ bed. The grass was weighed with a spring scale to provide the required weight for each treatment. The mulch intensity treatment based on their weight and depth as reported by Hudu et al. (2002) were $0 \mathrm{~cm}(0 \mathrm{t} / \mathrm{ha}), 2 \mathrm{~cm}(2.5 \mathrm{t} / \mathrm{ha}), 4 \mathrm{~cm}(5 \mathrm{t} / \mathrm{ha}), 6 \mathrm{~cm}(7.5 \mathrm{t} / \mathrm{ha}), 8 \mathrm{~cm}(10 \mathrm{t} / \mathrm{ha})$ and $10 \mathrm{~cm}(12.5 \mathrm{t} / \mathrm{ha})$. The mulch was spread manually by hand to each plot and the seedlings were transplanted thereafter. Seedlings were transplanted (5 weeks after sowing in the nursery) when they attained transplanting stage. The plots were watered to field capacity before transplanting the seedlings at spacing of spacing of $60 \mathrm{~cm} \times 60 \mathrm{~cm}$. A day after transplanting, water was applied at field capacity to each plot at the evening time. Subsequently, the plots were irrigated at four-day intervals until final harvest.

Data collection on the plant parameters were started two weeks after transplanting (WAT) from the four central plants, all the plants in the plot were used to determine percentage of plants that flowered over time in all the three replications. Parameters were measured were: Plant height, number of leaves, leaf area, leaf area index, number of branches per plant percentage of plants that flowered over time, Number of fruits per plant, Weight of fruits per plant, and Yield of fruits ( $\mathrm{t} / \mathrm{ha})$. Data collected were subjected to correlation analysis at $1 \%$ and $5 \%$ level of significance using statistical software Statistix 8.0. Results were presented for the two years combined.

\section{RESULTS}

Table 1, shows the correlation coefficient (r) among the agronomic parameters as affected by cultivar. Fruit yield was significantly and positively correlated with plant height, number of leaves, leaf area, leaf area index, days to first flowering and weight of fruits but significantly negatively correlated with days to $50 \%$ flowering. Plant height had significant positive correlation with number of leaves, leaf area, leaf area index, number of branches, number of fruits and significant negative correlation with days to first and $50 \%$ flowering and weight of fruits. Number of leaves had significant positive correlation with leaf area, leaf area index and number of branches and significant negative correlation with weight of fruits. Leaf area had significant positive correlation with leaf area index, number of branches and significant negative correlation with days to $50 \%$ flowering, number of fruits and weight of fruits. Leaf area index had significant positive correlation with number of branches and a significant negative correlation with days to $50 \%$ flowering number of fruits and weight of fruits. Number of branches had significant positive correlation with days to first and $50 \%$ flowering and number of fruits. Days to first flowering had significant positive correlation with days to $50 \%$ flowering, number of fruits and weight of fruits. Days to $50 \%$ flowering had significant positive correlation with number of fruits and weight of fruits. Number of fruits had significant positive correlation with weight of fruits. 
Table 1. Correlation Coefficient (r) Among the Agronomic Parameters Measured as Affected by Cultivar for the Combined Years.

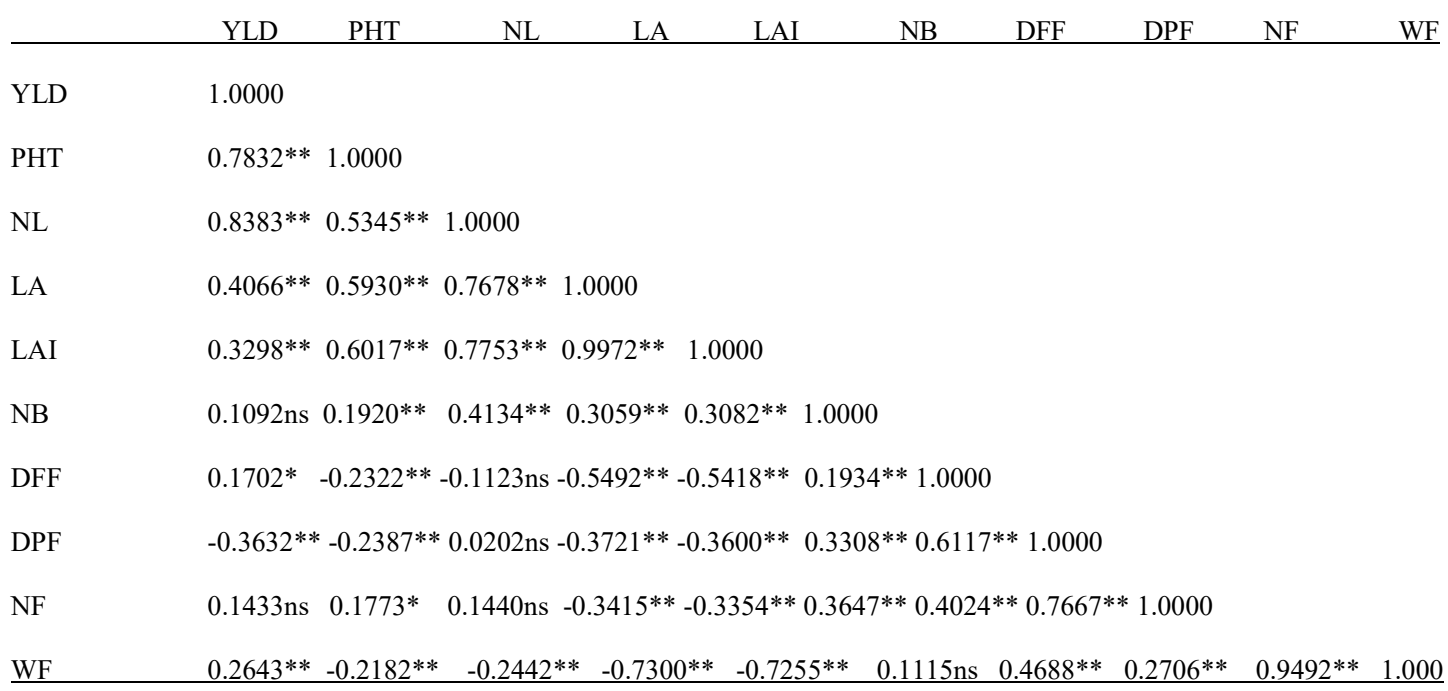

YLD $=$ Fruit Yield $(t / h a), \quad$ PHT $=$ Plant Height, $\mathrm{NL}=$ Number of Leaves, LA $=$ Leaf Area, LAI $=$ Leaf Area Index, NB $=$ Number of Branches, DFF = Days to First Flowering, DPF $=$ Days to $50 \%$ Flowering, NF $=$ Number of Fruits, WF $=$ weight of fruits,

$* *=$ Significant at $1 \%, *=$ Significant at $5 \%, \mathrm{~ns}=$ not significant

\section{1. Correlation Coefficient (r) Among Agronomic Parameters Measured as Affected by Mulching for the combine years}

Table 2 shows the correlation coefficient (r) among the agronomic parameters as affected by mulching. Fruit yield was significantly and positively correlated with plant height, number of leaves, leaf area, leaf area index days to first flowering, number of fruits and weight of fruits but significantly negatively correlated with number of branches and days to $50 \%$ flowering.

Plant height had significant positive correlation with number of leaves, leaf area, leaf area index, number of branches and significant negative correlation with days to first and 50 $\%$ flowering. Number of leaves had significant positive correlation with leaf area, leaf area index and number of branches. Leaf area had significant positive correlation with leaf area index, number of branches and significant negative correlation with days to first and $50 \%$ flowering, number of fruits and weight of fruits.

Leaf area index had significant positive correlation with number of branches and a significant negative correlation with days to first and $50 \%$ flowering, number of fruits and weight of fruits.

Number of branches had significant positive correlation with days to first and $50 \%$ flowering and number of fruits and weight of fruits. Days to first flowering had significant positive correlation with days to $50 \%$ flowering, number of fruits and weight of fruits. Days to $50 \%$ flowering had significant positive correlation with number of fruits and weight of fruits. Number of fruits had significant positive correlation with weight of fruits. 
Table 2. Correlation Coefficient (r) Among the Agronomic Parameters Measured as Affected by Mulching for the Combined Years.

\begin{tabular}{|c|c|c|c|c|c|c|c|c|c|c|}
\hline & YLD & PHT & NL & LA & LAI & NB & DFF & DPF & $\mathrm{NF}$ & WF \\
\hline YLD & 1.0000 & & & & & & & & & \\
\hline PHT & $0.8613^{* *}$ & 1.0000 & & & & & & & & \\
\hline NL & $0.8801 * *$ & $0.5417 * *$ & 1.0000 & & & & & & & \\
\hline LA & $0.1582 *$ & $0.4789 * *$ & $0.7647^{* *}$ & 1.0000 & & & & & & \\
\hline LAI & $0.3368^{* *}$ & $0.4811 * *$ & $0.7651^{* *}$ & $0.9980 * *$ & 1.0000 & & & & & \\
\hline NB & $0.1372 \mathrm{~ns}$ & $0.2340 * *$ & $0.4395 * *$ & $0.3248 * *$ & $0.3262 * *$ & 1.0000 & & & & \\
\hline DFF & $0.1693 *$ & $-0.2209 * *$ & $-0.0023 n s$ & $-0.3733 * *$ & $-0.3674 * *$ & $0.2337 * * 1.0000$ & & & & \\
\hline DPF & $-0.3331 * *$ & $-0.3346 * *$ & $-0.0026 n s$ & $-0.2226^{* *}$ & $-0.2124 * *$ & $0.2777 * * 0.5589 * *$ & 1.0000 & & & \\
\hline NF & $0.1955^{* *}$ & $0.1130 \mathrm{~ns}$ & $-0.0826 \mathrm{~ns}$ & $-0.6381 * *$ & $-0.6382 * *$ & $0.2002 * * 0.5045^{* *}$ & $0.2076^{* *}$ & 1.0000 & & \\
\hline $\mathrm{WF}$ & $0.4084 * *$ & $0.0396 \mathrm{~ns}$ & $-0.1029 \mathrm{r}$ & $-0.654 \mathrm{C}$ & -0.65 & $0.1541^{*}$ & $0.5674 * *$ & $0.2205^{* *}$ & $0.9541^{* *}$ & 1.000 \\
\hline
\end{tabular}

YLD $=$ Fruit Yield $(\mathrm{t} / \mathrm{ha}), \mathrm{PHT}=$ Plant Height, $\mathrm{NL}=$ Number of Leaves, LA $=$ Leaf Area, LAI $=$ Leaf Area Index, NB $=$ Number of Branches, DFF $=$ Days to First Flowering, DPF $=$ Days to $50 \%$ Flowering, NF = Number of Fruits, WF = weight of fruits

$* *=$ Significant at $1 \%, *=$ Significant at $5 \%$, ns $=$ not significant

\section{DISCUSSION}

The correlation as affected by cultivars of tomato studied positively correlated with Positive correlation between yield and plant height, number of leaves, leaf area, leaf area index, days to first flowering and weight of fruits, such correlations in tomato was observed by Mahapatra et al. (2013); Haydar et al. (2007). However, fruit yield was negatively correlated with days to $50 \%$ flowering. That means the uniformily of the flowering should not be a thing of concern during the heat period and this might not be unrelated to the detrimental effect of high temperature on the flowering of tomato (Pressman et al., 2002). Negative correlation of days to $50 \%$ floweing to number of fruits have been reported by (Akinfasoye et al., 2011).

Days to first flowering exhibited positive correlation with days to $50 \%$ flowering, number of fruits and weight of fruits, hence the improvement of days to first flowering overcomes problem of yield of tomato during heat period. Studies have shown the beneficial effect of mulch on tomato productivity during heat period (Quinn, 1975; Ashrafuzaman et al., 2010; Wali and Kabura 2013).

The study of correlation effect of mulching on parameters of tomato revealed significantly positive correlation of yield with plant height, number of leaves, leaf area, leaf area index days to first flowering, number of fruits and weight of fruits. Days to first flowering exhibited positive correlation with days to $50 \%$ flowering, number of fruits and weight of fruits exhibiting similar trend to the effect of cultivar. This suggests that the improvement of the character that influences attainment of first flowering influences the fruit yield of tomato under mulch during the heat period in the semi arid region of Nigeria. 


\section{CONCLUSIONS}

The growth and yield of tomato during the heat period is highly affected by the high temperature even when temperature regulation materials such as mulch were applied. Selection cannot be reliably inferred from fruit weight or plant height but from characters correlation for high yield. For both the cultivars studied and mulch applied, the study indicated that days to first flowering exhibited positive correlation with days to $50 \%$ flowering, number of fruits and weight of fruits, hence the plants that attain flowering earlier can be selected for high fruit yield production of tomato during heat period in the semi arid region of Nigeria..

\section{References}

[1] Adil H. A., N. Gruda (2005). Impact of high temperature on the growth and development of tomato during summer in the Arid Tropics. Deutscher Tropentag October 11-13, 2005, Hohenheim.

[2] Akinfasoye J. Akindele, Dotun J. Ogunniyan, Emmanuel O. Ajayi, American-Eurasian Journal of Agronomy 4(1) (2011) 17-22.

[3] Ashrafuzzaman M., M. A. Haque, M. R. Ismail, M. T. Islam, S. M. Shahidullah, International Journal of Botany 6(1) (2010) 41-46.

[4] BOSADP (1993). Croppping Reccomendation for Borno State. Borno State Agricultural Development Programme.

[5] Harel D. H. Fadida, A. Slepoy, S. Gantz, K. Shilo, Agronomy 4 (2014) 167-177.

[6] Haydar A. M., A. Mandal, M. B. Ahmed, M. M. Hannan, R. Karim, M. A. Razvy, U. K. Roy, M. Salahin, Middle-East Journal of Scientific Research 2(3-4) (2007) 139-142.

[7] Hudu A. I., Futuless L. N., N. A. Gworgwor, Journal of Sustainable Agriculture 21(2) (2002) 37-45.

[8] Kabura B. H., P. E. Odo, A. Abubakar, Journal of Agronomy 8(1) (2009) 45-48.

[9] LaI R., D. de Vieeschauwer, M. R. Nganje, American Journal of Soil Science Society 44 (1980) 827-833.

[10] Lawan M. (2006). Evaluation of tomato cultivar and cultural practices for the control of tomato fruit worm Helicoverpa (heliothis) armigera HUBNER (Lepideptera: Nuctuidae) in Maiduguri, Sudan Savanna of Nigeria. A Post-graduate PhD. Thesis, Department of Crop Protection, University of Maiduguri, Nigeria, Unpublished.

[11] Mahapatra A. S., Anand K. Singh, V. Manju Vani, Ramanand Mishra, Harit Kumar, B. V. Rajkumar, Int. J. Curr. Microbiol. App. Sci. 2(9) (2013) 147-152

[12] Maged A. E., Journal of Applied science Research 2(2) (2006) 67-73.

[13] Mata V. H., Nunez R., Sanchez P. G., Soil temperature and soil moisture in Serrano pepper (Capsicum ananum L.) with fertigation and mulching. Proceedings of 16th International Conference Paper. Tampico, Tamaulipas, Mexico November 10-12, 2002. 
[14] Mitterbauer E., Eseb E. (2007). Germplasm diversity for resource protection in crop production conference for International Agricultural Research for Development Tropentag, October 9-11.

[15] Orzolek M. D., The Vegetable Gazette 4(10) (2000) 12-17.

[16] Pressman E., Peet M. M., Pharr D. M., Ann. Bot. 90 (2002) 631-636.

[17] Quinn J. G., Horticultural Research 15 (1975) 31-39.

[18] Rodriguez G. R., Cien. Inv. Agr. 34(3) (2007) 181-186.

[19] Sakar S., Paramanick M., S. B. Goswami, Soil and Tillage Research 93 (2007) 94-101.

[20] Samaila A. A., E. B. Amans, B. A. Babaji, International Research. Journal of Agricultural Science 1(3) (2011) 90-95.

[21] Wali A. S., Kabura B. H., International Journal of Agricultural Innovations 3(1) (2013).

[22] D. M. Mailafiya, M. M. Degri, Y. T. Maina, U. N. Gadzama, I. B. Galadima, International Letters of Natural Sciences 5 (2014) 45-54. 